\title{
Fiber concentrates from asparagus by-products: Microstructure, composition, functional and antioxidant properties
}

\section{Concentrados fibrosos a partir de subprodutos de aspargo: Microestrutura, composição e propriedades funcionais e antioxidantes}

\author{
Isabela Julio Iwassa ${ }^{1 *} \mathbb{D}$, Juliana Francis Piai² ${ }^{\mathbb{D}}$, Beatriz Cervejeira Bolanho3 ${ }^{\mathbb{D}}$
}

\author{
'Universidade Estadual de Maringá/UEM, Departamento de Engenharia Química, Maringá, PR, Brasil \\ IInstituto Federal do Paraná/IFPR, Astorga, PR, Brasil \\ ${ }^{3}$ Universidade Estadual de Maringá/UEM, Departamento de Tecnologia, Umuarama, PR, Brasil \\ *Corresponding author: isa_iwassa@hotmail.com \\ Received in April 4, 2019 and approved in August 7, 2019
}

\begin{abstract}
The by-product of asparagus processing has a high content of nutrients and bioactive compounds. Based on this, it becomes interesting to investigate treatment options to obtain a product with better nutritional quality, avoiding its waste and environmental impact. The aim of this study was to produce and characterize fiber concentrates from asparagus by-products. Water extraction treatments were realized in homogenizer $(\mathrm{H})$, water bath $(\mathrm{B})$, shaker $(\mathrm{S})$ and ultrasound $(\mathrm{U})$. One sample was not submitted to water extraction (control). All the products obtained were dried and milled before the characterization analysis. In relation to color, the concentrates obtained by $\mathrm{U}, \mathrm{H}$ and $\mathrm{S}$ treatments had the highest luminosity (66.5 to 69.8). The index of water and oil absorption of the fiber concentrates ranged from 11.8 to $14.7\left(\mathrm{~g} \mathrm{~g}^{-1}\right)$ and 6.1 to $8.9\left(\mathrm{~g} \mathrm{~g}^{-1}\right)$, respectively. The analysis of scanning electron microscopy showed the effect of processing

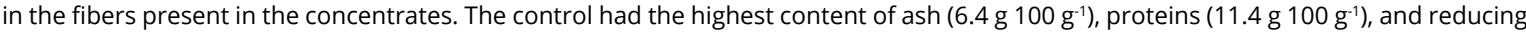

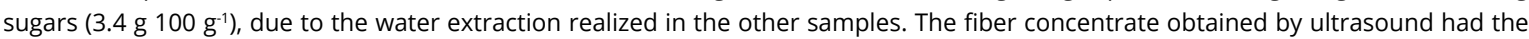
best proportion of soluble fiber to insoluble fiber and antioxidant potential similar to the control, so, among the treatments tested it is the most recommended to the formulation of functional food products.
\end{abstract}

Index terms: Phenolics compounds; dietary fiber; ultrasound.

\begin{abstract}
RESUMO
O subproduto do processamento de aspargo possui alto teor de nutrientes e compostos bioativos. Com base nisto, torna-se interessante a investigação de opções de tratamento para a obtenção de produto com melhor qualidade nutricional evitando seu desperdício e, consequentemente, seu impacto ambiental. O objetivo deste trabalho foi produzir e caracterizar concentrados de fibras do subproduto de aspargo. Os tratamentos de extração com água foram realizados em homogeneizador (H), banho-Maria (B), agitação em Shaker (S), ultrasom (U). Uma amostra não foi submetida a extração aquosa (controle). Todos os produtos foram secos e moídos antes das análises de caracterização. Em relação à cor, os concentrados obtidos pelos tratamentos U, H e S apresentaram maior luminosidade $(66,5$ a 69,8). O índice de absorção de água e de óleo dos concentrados variou de 11,8 a 14,7 ( $\left.\mathrm{g} \mathrm{g}^{-1}\right)$ e 6,1 a 8,9 ( $\left.\mathrm{g} \mathrm{g}^{-1}\right)$, respectivamente. A análise de microscopia eletrônica de varredura mostrou o efeito do processamento nas fibras presentes nos concentrados. O controle apresentou maior teor de cinzas $\left(6,4 \mathrm{~g} 100 \mathrm{~g}^{-1}\right)$, proteínas $\left(11,4 \mathrm{~g} 100 \mathrm{~g}^{-1}\right)$ e açúcares redutores $\left(3,4 \mathrm{~g} 100 \mathrm{~g}^{-1}\right)$, devido à extração com água realizada nas demais amostras. O concentrado obtido pelo tratamento com ultrasom apresentou a melhor proporção entre o teor de fibra solúvel e insolúvel, bem como, potencial antioxidante semelhante ao controle, então, entre os tratamentos de extração realizados, este é o mais recomendado para a formulação de produtos alimentares funcionais.
\end{abstract}

Termos para indexação: Compostos fenólicos; fibra alimentar; ultrassom.

\section{INTRODUCTION}

The production of asparagus (Asparagus officinalis L.) has been growing since the 90 's, reaching a global crop of about $8.7 \times 10^{6} \mathrm{Tm}$ in 2016 (FAO, 2018). Asparagus is an important vegetable to consumption due to its low energy value and high amount of nutrients and bioactive compounds, such as fibers and phenolics (Zhao et al., 2011). Studies demonstrate that asparagus components have many biological activities, including antifungal, anti-inflammatory and antioxidant (Fuentes-Alventosa et al., 2009a; Tsushida; Suziki; Kurogi, 1994; Zhao et al., 
2011). Tsushida, Suziki and Kurogi (1994) reported that among 43 vegetables analyzed, asparagus had the highest antioxidant potential. The consumption of high amounts of antioxidants is important due to their capacity of scavenge free radicals and protect the human body from oxidative stress, which is the main cause of some cancers and heart diseases (Tabaszewska et al., 2018).

The edible part of asparagus has $25 \mathrm{~cm}$ to $35 \mathrm{~cm}$ length, and its non-edible part (stem) corresponds to about one third of the total length of asparagus spear (Zhao et al., 2011). In order to extend the shelf life of this vegetable, food industries produce canned or frozen asparagus (Sun; Tang; Powers, 2005). During these processing, the fibrous stem is discarded and it represents a significant amount of by-product (about $50 \%$ of total weight), that has low value, despite its high nutritional content (Fuentes-Alventosa et al., 2009a).

Different products can be used as source of dietary fiber, especially the waste obtained after fruit and vegetable processing (Ayala-Zavala et al., 2011). Dietary fibers are polymeric compounds which resist to hydrolysis, digestion and absorption in small intestine, with partial or complete fermentation in the large intestine that stimulates a better intestinal activity (Dang; Vasanthan, 2019). Fibers have an important role in the health due to their beneficial physiological effects such as lowering cholesterol and obesity, preventing cardiovascular and gastrointestinal diseases and also helping to minimize the level of glucose in the blood (Mudgil; Barak; Khatkar, 2012). Because of these effects, there is a growing demand for new sources of dietary fiber to be added to food products; this nutrient also had important functional properties, like water and oil absorption, thickening and gelling (Cadavid; Molina; Valenzuela, 2015). The fiber-rich waste can be used to promote viscosity, texture and nutritional characteristics of food products. The total or partial replacement of wheat flour by flours or fiber concentrates obtained from by-products is a branch to food industry that can provide to the market enriched nutrient products with low cost (Elleuch et al., 2011). To obtain fiber concentrates, various methods can be employed, however, there is a tendency of extraction procedures that may increase production efficiency and contribute to environmental preservation by reducing the use of water and solvents, elimination of wastewater, fossil energy and generation of hazardous substances (Chemat et al., 2017).

Considering the high amount of asparagus by-products generated in the food industry and their nutritional value, it is important to promote their utilization to stimulate the productive chain of asparagus (ViudaMartos et al., 2012). So, the aim of this work was to produce fiber concentrates from asparagus by-products using different treatments and characterize them as composition, antioxidant and functional properties.

\section{MATERIAL AND METHODS}

The asparagus were obtained in a productive centre of Marialva (Paraná - Brazil). The by-product was separated from the edible part by cutting the fibrous stem using a knife. The edible part and the by-product were ground in a domestic blender (Mondial, Manaus, Brazil).

To fiber concentrate production, a portion of the ground residue was subjected to water extraction, in the proportion 1:1 weight/volume, following different treatments: agitation in homogenizer (MA 259, Marconi, Piracicaba, Brazil) at $25^{\circ} \mathrm{C}$ for $30 \mathrm{~min}$ and $1.67 \mathrm{~Hz}$, orbital agitation in shaker (MA 832, Marconi) at $25^{\circ} \mathrm{C}$ for 120 min and $3.33 \mathrm{~Hz}$, heating in water bath (MA 127, Marconi) at $80^{\circ} \mathrm{C}$ for $60 \mathrm{~min}$, and agitation in ultrasound bath $(25$ $\mathrm{kHz}, \mathrm{Q} 59 / 24 \mathrm{~A}$, Ultronique, Indaiatuba, Brazil) at $25^{\circ} \mathrm{C}$ for $60 \mathrm{~min}$; being the frequencies defined as the maximum value of each equipment and the time and temperature were chosen based in previous studies (Bolanho; Danesi; Beléia, 2014; Cadavid; Molina; Valenzuela, 2015). After these procedures, the aqueous extract was removed by pressing in sieves. Part of the by-product previous ground was not submitted to aqueous extraction (control treatment). All the treatments were dried in oven with forced air circulation $\left(035 / 5\right.$, Marconi) at $50^{\circ} \mathrm{C}$ for $16 \mathrm{~h}$, followed by ground in knife mill type Willye (SL-031, Solab, Piracicaba, Brazil). The particle size separation was realized in mechanical stirrer sieves (Marconi), using sieves Tyler (Bertel, Caieiras, Brazil) from 150 to $600 \mu \mathrm{m}$. The concentrates with particle size of $150 \mu \mathrm{m}$ were utilized in the analyzes. All fiber concentrate production processes and the analyzes performed for them are represented by the scheme described in Figure 1.

The edible part and the by-product of asparagus fresh, and the fiber concentrates produced were analyzed for chemical composition by AOAC methods: moisture (method 925.09), ashes (method 923.03), proteins (method 920.87), lipids (method 920.85) and total carbohydrates (determined by difference). The fiber concentrates were also analyzed as reducing and not reducing sugars (method 945.66) and total, soluble and insoluble dietary fiber (method 991.43) (Horwitz; Latimer, 2005). 


\section{TREATAMENTS}

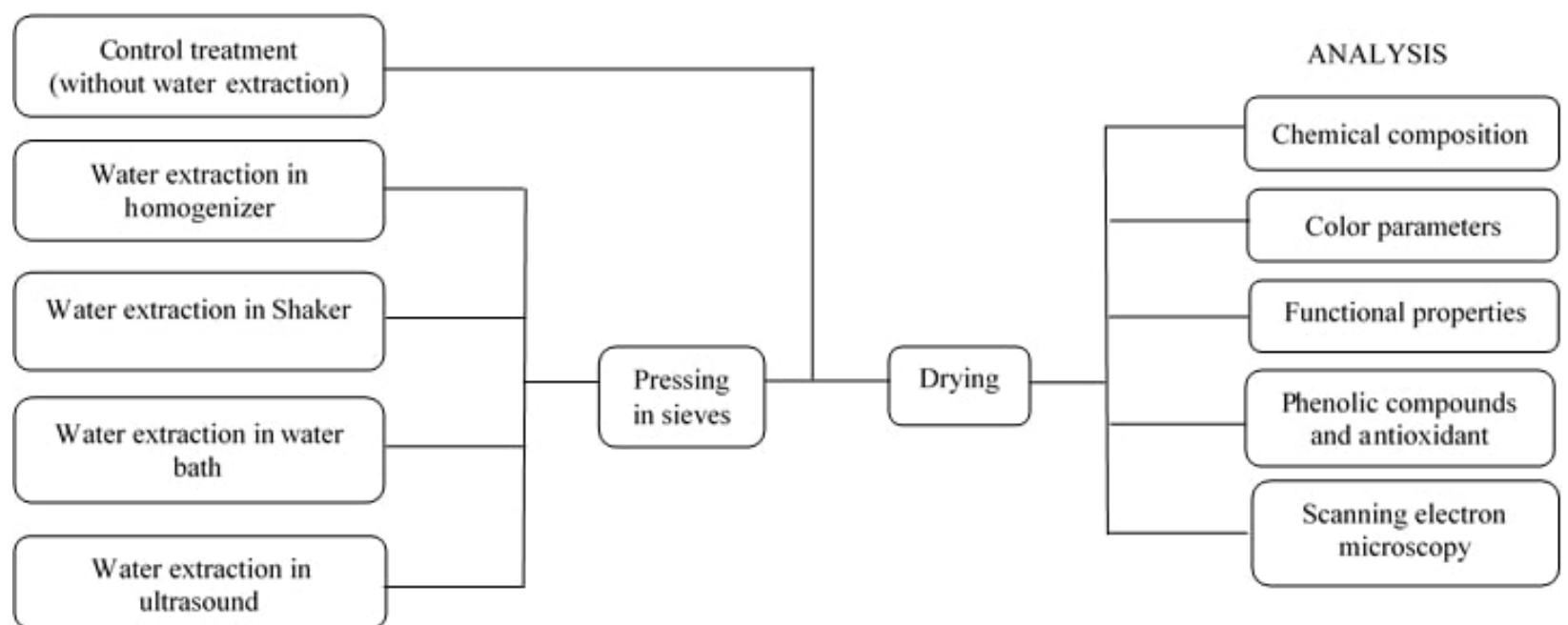

Figure 1: Scheme of the production of fiber concentrates and characterization analyzes.

The color characteristics of the fiber concentrates were defined by the parameters of CIE-Lab, $\mathrm{L}^{*}$ (lightness), $+\mathrm{a}^{*}$ (red) $-\mathrm{a}^{*}$ (green), and $+\mathrm{b}^{*}$ (yellow) $-\mathrm{b}^{*}$ (blue) using the colorimeter Color Reader CR-10 (Konica Minolta, Chiyoda, Japan). The hue angle $\left(\mathrm{H} / \mathrm{h}^{\circ}\right)$ was calculated according to the Equation 1 (Mclellan; Lind; Kime, 1995). The color difference $\left(\Delta \mathrm{E}^{*}\right)$ of the samples treated in relation to the control $\left(\mathrm{L}_{0}, \mathrm{a}_{0}\right.$ and $\left.\mathrm{b}_{0}\right)$ sample was calculated with the Equation 2, using the mean values of $\mathrm{L}^{*}, \mathrm{a}^{*}$ and $\mathrm{b}^{*}$.

$H\left(h^{\mathrm{o}}\right)=180+\tan ^{-1}\left(\frac{b^{*}}{a^{*}}\right)$

$\Delta E=\sqrt{\left(L^{*}-L_{0}\right)^{2}+\left(a^{*}-a_{0}\right)^{2}+\left(b^{*}-b_{0}\right)^{2}}$

The water solubility index (WSI) of fiber concentrates was evaluated according to Aziz et al. (2011) and the results were expressed in grams of soluble solids per $100 \mathrm{~g}$ of dried sample. The water absorption index (WAI) was measured weighing $2 \mathrm{~g}$ of sample in centrifuge tube, adding $20 \mathrm{~mL}$ of water and the mixture was stirred continuously in a shaker at $1.25 \mathrm{~Hz}$ for $30 \mathrm{~min}$. The mixture was centrifuged (MTD III plus, Metroterm, Porto Alegre, Brazil) at $3000 \mathrm{xg}$ for $10 \mathrm{~min}$, the supernatant was discarded and the residue was weighed. WAI was obtained by the weight ratio between the wet sediment and the dry matter. The oil absorption index (OAI) was determined in the same way as the water absorption, but using commercial soybean oil (Cocamar, Maringá, Brazil). The results are expressed in gram of water or oil absorbed per gram of dry matter (Seibel; Beléia, 2009).

The antioxidant extraction was carried out using $1 \mathrm{~g}$ of sample and $10 \mathrm{~mL}$ of hydroethanolic solution (ethanol: water, 80:20, v. $\mathrm{v}^{-1}$ ), with shaker agitation at $1.67 \mathrm{~Hz}$ for $4 \mathrm{~h}$ (Hung et al., 2009). The ethanolic extract was obtained after filtration, and it was directly used for the determination of total phenolic compounds (TPC) using Folin-Ciocalteu method (Swain; Hillis, 1959). An analytical curve was prepared with gallic acid (Sigma-Aldrich, Saint Louis, Missouri, USA) with concentrations of 0.1 to $0.5 \mathrm{mM}$, presenting regression coefficient $(\mathrm{R})$ of 0.99 . The results were expressed in milligrams of gallic acid equivalent per 100 grams of sample. With the same extracts the antioxidant activity (AA) was measured by different methods. The radical scavenging activity toward DPPH radicals (2,2-diphenyl-1-picrylhydrazyl, Sigma-Aldrich) was determined using $1 \mathrm{~mL}$ of acetate buffer $100 \mathrm{mmol} \mathrm{L}^{-1}$ $\mathrm{pH} 5.5,1 \mathrm{~mL}$ of ethanol, $0.5 \mathrm{~mL}$ of DPPH $250 \mu \mathrm{mol} \mathrm{L}^{-1}$ and $50 \mu \mathrm{L}$ of the extract. After $30 \mathrm{~min}$, the absorbance was read at $517 \mathrm{~nm}$ in the spectrophotometer (700 Plus, Femto, São Paulo, Brazil) (Brand-Wiliams; Cuvelier; Berset, 1995). The ferric reducing antioxidant power (FRAP) of the extracts was realized with $2.7 \mathrm{~mL}$ of FRAP reagent, $90 \mu \mathrm{L}$ of sample and $270 \mu \mathrm{L}$ of distilled water. After $30 \mathrm{~min}$, the absorbance was read at $595 \mathrm{~nm}$ in the spectrophotometer (700 Plus, Femto) (Benzie; 
Strain, 1996). The results of these methodologies are expressed as micromoles of Trolox (6-hydroxy-2,5,7,8tetramethylchroman-2-carboxylic acid, Sigma-Aldrich) equivalent per gram of sample.

The microstructure of fiber concentrates was analyzed by scanning electron microscopy (model Quanta 200, FEI, Hillsboro, Oregon, USA), after coating the samples with gold in the Sputter Coater (SCD 050, BaltecBalzers, New York City, New York, USA).

Analyses were done in three replicates and the results were expressed as mean \pm standard derivation. The variance analysis followed by Tukey test and the Person correlation test $(p<0.05)$ were performed using the software Statistica version 6.0 (StatSoft, Tulsa, Oklahoma, USA).

\section{RESULTS AND DISCUSSION}

The results for composition of fresh samples showed that the edible part of asparagus has higher

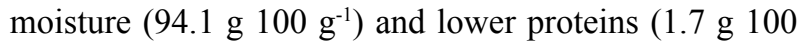
$\left.\mathrm{g}^{-1}\right)$ and total carbohydrates content $\left(3.2{\left.\mathrm{~g} 100 \mathrm{~g}^{-1}\right)(p<}\right.$ $0.05)$ than that found in its by-product $(92.6,1.0$ and 5.7 g $100 \mathrm{~g}^{-1}$, respectively); being the ashes $\left(0.6{\left.\mathrm{~g} 100 \mathrm{~g}^{-1}\right) \text { and }}^{-1}\right.$

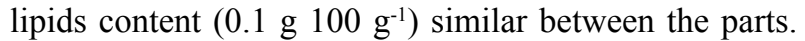
Tabaszewska et al. (2018) reported in fresh asparagus

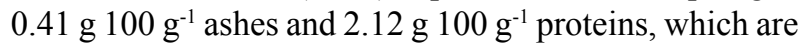
similar to that found in this study.

The fiber concentrate produced from asparagus by-products without aqueous extraction step (control) had ashes, proteins and reducing sugars content higher than the other treatments (Table 1). The different methods of water extraction were performed to concentrate the fiber content and to obtain better functional properties, but they also caused solubilization of sugars, proteins and ashes.
The concentrates produced had a lower protein content than that obtained for asparagus by-product exposed to intense treatment $\left(90 \mathrm{~min}\right.$ and $\left.60^{\circ} \mathrm{C}\right)$ with water followed

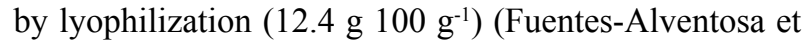
al., 2009b). Lipids and not reducing sugars were detected in low concentration in the samples $(<0.5 \%$, data not showed), contributing to the low energy value of the concentrates studied, which is important to their utilization in the formulation of low-caloric foods. The pressing step realized after water extraction treatments decreased the moisture of the concentrates when compared with the control treatment. The pressing step can minimize the drying time, contributing to decrease the energy consumption in the process. The total dietary fiber (DF) content in the concentrates ranged from 62.9 to $67.7 \mathrm{~g}$ $100 \mathrm{~g}^{-1}$, values similar to that found in by-products flours

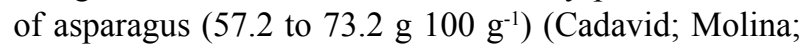
Valenzuela, 2015). The high DF content is important due to its beneficial action to the consumer health, and its addition in food formulations can make then functional, according to the fiber content of the final product (Dang; Vasanthan, 2019).

The highest insoluble dietary fiber content was

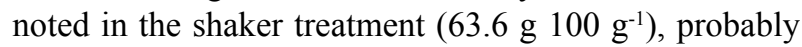
due to the solubilization of compounds, like sugars and proteins, which concentrates the insoluble fiber content. This value was similar to that obtained for the asparagus by-product meal after a treatment using subcritical water

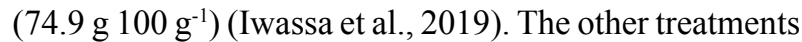
studied had an insoluble dietary fiber content similar to that found in asparagus by-product fiber concentrates

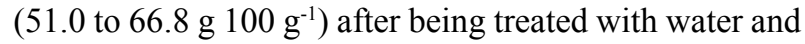
ethanol followed by drying in the oven or by lyophilization (Fuentes-Alventosa et al., 2009b).

Table 1: Proximate composition ( $100 \mathrm{~g}^{-1}$ ) of fiber concentrates from asparagus by-products(1).

\begin{tabular}{|c|c|c|c|c|c|c|c|}
\hline Treatment & Moisture & Ash & Proteins & Reducing sugars & Insoluble DF(2) & Soluble $\mathrm{DF}^{(2)}$ & Total DF(2) \\
\hline Control & $\begin{array}{c}15.2 \pm \\
0.3^{\mathrm{a}}\end{array}$ & $\begin{array}{l}6.4 \pm \\
0.1^{a}\end{array}$ & $\begin{array}{c}11.3 \pm \\
0.4^{a}\end{array}$ & $\begin{array}{l}3.4 \pm \\
0.1^{a}\end{array}$ & $\begin{array}{c}57.2^{ \pm \pm} \\
0.2^{c}\end{array}$ & $\begin{array}{l}6.2^{ \pm} \\
0.3^{b}\end{array}$ & 63.4 \\
\hline Homogenizer & $\begin{array}{c}10.6 \pm \\
0.1^{b}\end{array}$ & $\begin{array}{l}3.9 \pm \\
0.2^{\mathrm{b}}\end{array}$ & $\begin{array}{l}9.4 \pm \\
0.9^{\mathrm{b}}\end{array}$ & $\begin{array}{l}1.6 \pm \\
0.0^{\mathrm{b}}\end{array}$ & $\begin{array}{c}61.3 \pm \\
1.2^{\mathrm{b}}\end{array}$ & $\begin{array}{l}6.4 \pm \\
0.4^{\mathrm{b}}\end{array}$ & 67.7 \\
\hline Water bath & $\begin{array}{c}10.1 \pm \\
0.2^{\mathrm{b}}\end{array}$ & $\begin{array}{l}3.9 \pm \\
0.2^{\mathrm{b}}\end{array}$ & $\begin{array}{l}9.4 \pm \\
0.1^{b}\end{array}$ & $\begin{array}{l}1.5 \pm \\
0.6^{b}\end{array}$ & $\begin{array}{c}57.0 \pm \\
0.7^{c}\end{array}$ & $\begin{array}{l}5.8 \pm \\
0.4^{\mathrm{b}}\end{array}$ & 62.9 \\
\hline Shaker & $\begin{array}{c}10.2 \pm \\
0.5^{b}\end{array}$ & $\begin{array}{l}3.1 \pm \\
0.2^{c}\end{array}$ & $\begin{array}{l}9.1 \pm \\
0.7^{b}\end{array}$ & $\begin{array}{l}2.0 \pm \\
0.0^{b}\end{array}$ & $\begin{array}{c}63.6 \pm \\
0.3^{\mathrm{a}}\end{array}$ & $\begin{array}{l}1.7 \pm \\
0.6^{c}\end{array}$ & 65.3 \\
\hline Ultrasound & $\begin{array}{c}10.8 \pm \\
0.1^{b}\end{array}$ & $\begin{array}{l}2.8^{ \pm} \\
0.1^{c}\end{array}$ & $\begin{array}{l}9.0 \pm \\
0.7^{b}\end{array}$ & $\begin{array}{l}1.6 \pm \\
0.2^{b}\end{array}$ & $\begin{array}{c}57.4 \pm \\
0.5^{c}\end{array}$ & $\begin{array}{l}9.1 \pm \\
0.0^{a}\end{array}$ & 66.5 \\
\hline
\end{tabular}

${ }^{(1)}$ Means values in the same column followed by the same letter are not significantly different $(p<0.05) .{ }^{(2)}$ Dietary fiber. 
The processing conditions can cause alterations in the cell wall material, resulting in modification of insoluble to soluble fibers (Kunzek et al., 2002). In the ultrasound treatment this alteration was observed, and it can be attributed to the wave propagation that generates a mechanical effect (Ferarsa et al., 2018), resulting in higher soluble fiber content and consequently, a better balance of soluble to insoluble fiber (1:6), than the values observed in the others treatments. An adequate balance of soluble to insoluble fiber is important due to the different properties of each fraction. The soluble fiber fraction is composed by pectin, gum, and some hemicelluloses and it is related to the decrease of cholesterol and postprandial glucose. Otherwise, the insoluble fiber is associated with intestinal transit regulation and it includes cellulose, lignin and the most part of hemicelluloses (Dang; Vasanthan, 2019).

The color and the functional properties (Table 2) are important to direct the application of a food ingredient. Despite the variation in $a^{*}$ and $b^{*}$ values, the hue angle was similar in the concentrates produced $\left(97.3\right.$ to $\left.102.8^{\circ}\right)$, which corresponds to the yellow quadrant.

The formulations obtained in water bath and without aqueous extraction (control) had the darkest color (low L* value), which can be due to the reactions of non enzymatic browning that occur in high temperatures and to the absence of aqueous extraction which removes some components (like pigments), respectively. The highest luminosity ( $\mathrm{L}^{*}$ ) was found in the concentrates produced by ultrasound, homogenizer and shaker treatments. The luminosity values detected in this study were higher when compared to that reported by Sergio et al. (2018) for asparagus spears treated by bleaching and microwave ( 46.4 and 44.2 , respectively).
The total color difference $\Delta \mathrm{E}^{*}$ (combination of $\mathrm{L}^{*}$, $\mathrm{a}^{*}$, and $\mathrm{b}^{*}$ values) is a colorimetric parameter extensively used to characterize the variation of color in foods during processing (Romdhane et al., 2015). The color change of the treated samples in relation to the control can be observed as $\Delta \mathrm{E}^{*}$ values. The lowest $\Delta \mathrm{E}^{*}$ was found in water bath treatment, due to its similar values of $\mathrm{L}^{*}$ and $\mathrm{b}^{*}$ in relation to the control, being this the treatment that presented greater preservation of the color. M'hiri et al. (2018) evaluated different methods of drying the byproduct of lemon, observing that microwave drying $(90 \mathrm{~W})$ and convective drying $\left(50^{\circ} \mathrm{C}\right)$ showed greater conservation of the natural color of the fresh lemon by-product, which tends to be green. Color is one of the most important parameters that directly influence the consumer's decision, and the lightness seems to be the most important factor in relation to color, since, the lighter products are easier incorporated into food formulations (Pszczola, 2008).

The control treatment had the highest water solubility index (WSI), probably due to its high sugar content that are not removed in the aqueous extraction. A positive correlation $(p<0.05)$ between the WSI values and the sugar content in the products analyzed corroborates to this affirmation. The values of WSI were lower than that observed in asparagus by-products flours (11.8 to $15.7 \mathrm{~g}$ $100 \mathrm{~g}^{-1}$ ) (Cadavid; Molina; Valenzuela, 2015).

The water absorption index (WAI) in the samples studied ranged from 11.8 to $14.7 \mathrm{~g} \mathrm{~g}^{-1}$. This parameter is directly related to the fiber structure of the sample, and the temperature used in the concentrate processing can modify the fiber, promoting the water absorption (Chen et al., 2013). This explains the high value of WAI detected in the

Table 2: Color parameters and functional properties of fiber concentrates obtained from asparagus by-products ${ }^{(1)}$.

\begin{tabular}{|c|c|c|c|c|c|}
\hline & Control & Homogenizer & Water bath & Shaker & Ultrasound \\
\hline \multicolumn{6}{|c|}{ Color properties } \\
\hline$L^{*(2)}$ & $59.7 \pm 0.7^{b}$ & $68.5 \pm 0.6^{a}$ & $62.3 \pm 0.0^{\mathrm{b}}$ & $66.6 \pm 0.7^{a}$ & $69.8 \pm 0.4^{a}$ \\
\hline$a^{*(3)}$ & $-2.1 \pm 0.1^{\mathrm{a}}$ & $-3.2 \pm 0.0^{\mathrm{b}}$ & $-3.6 \pm 0.2^{c, d}$ & $-3.9 \pm 0.0^{d}$ & $-3.4 \pm 0.1^{b, c}$ \\
\hline$b *(4)$ & $16.2 \pm 0.4^{d}$ & $18.7 \pm 0.3^{b}$ & $16.0 \pm 0.3^{d}$ & $17.4 \pm 0.2^{c}$ & $20.2 \pm 0.2^{a}$ \\
\hline $\mathrm{H}\left[{ }^{\circ}\right]^{(5)}$ & $97.3 \pm 2.3^{a}$ & $99.7 \pm 1.4^{a}$ & $102.8 \pm 3.0^{a}$ & $102.7 \pm 3.5^{\mathrm{a}}$ & $99.5 \pm 2.7^{a}$ \\
\hline$\Delta \mathrm{E}^{\star(6)}$ & & 11.7 & 4.3 & 9.2 & 15.4 \\
\hline \multicolumn{6}{|c|}{ Functional properties } \\
\hline$W S I^{(7)}\left(g \quad 100 g^{-1}\right)$ & $7.6 \pm 0.3^{a}$ & $4.1 \pm 0.2^{\mathrm{b}}$ & $2.3 \pm 0.1^{c}$ & $2.7 \pm 0.1^{c}$ & $2.4 \pm 0.1^{c}$ \\
\hline$W A I^{(8)}\left(\mathrm{g} \mathrm{g}^{-1}\right)$ & $11.8 \pm 0.1^{d}$ & $13.2 \pm 0.5^{b, c}$ & $14.7 \pm 0.5^{\mathrm{a}}$ & $13.9 \pm 0.1^{a, b}$ & $13.0 \pm 0.1^{c}$ \\
\hline$O A I^{(9)}\left(\mathrm{g} \mathrm{g}^{-1}\right)$ & $6.1 \pm 0.3^{d}$ & $7.2 \pm 0.1^{\mathrm{b}, \mathrm{c}}$ & $7.0 \pm 0.1^{c}$ & $8.9 \pm 0.1^{a}$ & $7.6 \pm 0.1^{b}$ \\
\hline
\end{tabular}

${ }^{(1)}$ Means values in the same line followed by the same letter are not significantly different $(p<0.05) .{ }^{(2)}$ Luminosity. ${ }^{(3)}$ Red to green color. ${ }^{(4)}$ Yellow to blue color. ${ }^{(5)}$ Hue angle. ${ }^{(6)}$ Color difference. ${ }^{(7)}$ Water solubility index. ${ }^{(8)}$ Water absorption index. ${ }^{(9)}$ Oil absorption index. 
concentrate produced after the treatment realized in water bath at $80^{\circ} \mathrm{C}\left(14.7 \mathrm{~g} \mathrm{~g}^{-1}\right)$. Elleuch et al. (2011) reported that the higher the water absorption, lower is the risk to occur syneresis and changes in the texture or viscosity of a food product, while the high oil absorption index (OAI) allows stabilizing foods with high fat content and emulsions. The OAI ranged from 6.1 to $8.9 \mathrm{~g} \mathrm{~g}^{-1}$ in the concentrates produced, values close to those found for asparagus byproducts subjected to a mild treatment with water, followed by drying in the oven $\left(7.7 \mathrm{~g} \mathrm{~g}^{-1}\right)$ (Fuentes-Alventosa et al., 2009b). The oil absorption capacity is also important because it is related to the retention of aroma and flavor (Jitngarmkusol; Hongsuwankul; Tananuwong, 2008).

It was found that the control and the ultrasound treatments had the highest content of total phenolic compounds (Table 3 ). It indicates that the water extraction step can cause loss of phenolic compounds, which did not occur in the ultrasound treatment, probably because of the mechanic effects that the cavitation bubbles generated in the equipment can cause in the sample. This effect modifies the physical and chemical properties of the material, facilitating the release of extractable compounds and it promotes a better mass transport to disrupt the cell wall material (Ferarsa et al., 2018). According to Chemat et al. (2017) the ultrasound extraction is considered a green process, due to the reduction in the time and in the energy consumption and the higher efficiency of processing.

Fan et al. (2015) found higher TPC content (443.0 to $1058.0 \mathrm{mg} 100 \mathrm{~g} \mathrm{~g}^{-1}$ ) in asparagus residues than those obtained in this work, probably due to use of different extraction solvent. The phenolic compounds had an aromatic ring with one or more hydroxyl groups, and this structure allows their chemical stability after donating an electron to a free radical (Oliveira; Carvalho; Melo, 2014). Therefore, the phenolic compounds are important in food products due to its antioxidant action that can prevent oxidative reactions that generate undesirable flavor compounds during the storage. Several flavonoids can be found in the group of phenolic compounds present in asparagus (edible portion), and among them, rutin highlights due to its antiviral action, in addition to the pharmacological activity as antiallergic, antibacterial and others (Guo; Wei; Liu, 2007).

In the concentrates produced the highest antioxidant activity (AA) evaluated by DPPH was found in the ultrasound treatment. The values detected in the concentrates are higher than that observed in grape peels $\left(10.6 \mu \mathrm{mol} \mathrm{g}^{-1}\right)$ (Rockenbach et al., 2011) and lower than the value found in avocado by-products flours (310.0 to $410.7 \mu \mathrm{mol} \mathrm{g}^{-1}$ ) (Daiuto et al., 2014). The highest AA by ferric reduction power (FRAP) methodology was recorded for control and ultrasound treatments. Bolanho, Danesi and Beléia (2014) noted lower AA in by-products flours from peach palm waste (8.6 to $10.9 \mu \mathrm{mol} \mathrm{g}^{-1}$ ). In this study, a significant correlation between FRAP values and total phenolic compounds content $(0.97, p<0.05)$ was observed, indicating that higher TPC higher is the AA by this method. During the metabolic processes the free radicals are produced continuously, which promote the development of many antioxidant defense mechanisms that limit the intracellular levels and prevent the damage induction (Vedana et al., 2008). In relation to DPPH and FRAP methods, the results obtained in this work showed that the concentrates produced had antioxidant capacity, probably due to the interaction of their components with free radicals or to promote the ferric reduction, lowering its potential of catalyze oxidative reactions.

The scanning electron microscopy analysis of concentrates produced from asparagus by-product (Figure 2) revealed the fibrous tissue disorganization due to the effect of the processing steps.

Table 3: Total phenolic compounds and antioxidant activity by DPPH and FRAP methods of fiber concentrates obtained from asparagus by-products ${ }^{(1)}$.

\begin{tabular}{cccc}
\hline \multirow{2}{*}{ Treatment } & \multirow{2}{*}{ Total phenolic compounds $\left(\mathrm{mg} 100 \mathrm{~g}^{-1}\right)$} & \multicolumn{2}{c}{ Antioxidant activity } \\
\cline { 3 - 4 } & $214.0 \pm 0.1^{\mathrm{a}}$ & $28.2 \pm 0.3^{\mathrm{c}}$ & $442.9^{\mathrm{a}} \pm 2.1^{\mathrm{a}}$ \\
Control & $165.3 \pm 0.0^{\mathrm{c}}$ & $33.9 \pm 1.4^{\mathrm{b}}$ & $314.6 \pm 1.2^{\mathrm{c}}$ \\
Homogenizer & $160.0 \pm 0.0^{\mathrm{d}}$ & $22.9 \pm 0.8^{\mathrm{c}}$ & $283.4 \pm 2.4^{\mathrm{d}}$ \\
Water bath & $181.8 \pm 0.1^{\mathrm{b}}$ & $38.1 \pm 4.1^{\mathrm{a}, \mathrm{b}}$ & $390.0 \pm 1.9^{\mathrm{b}}$ \\
Shaker & $210.7 \pm 0.1^{\mathrm{a}}$ & $40.2 \pm 0.1^{\mathrm{a}}$ & $441.0 \pm 1.9^{\mathrm{a}}$ \\
Ultrasound & &
\end{tabular}

(1) Means values in the same column followed by the same letter are not significantly different $(p<0.05)$. Total phenolic compounds are expressed as gallic acid equivalents. Antioxidant activity is expressed in Trolox equivalents. 

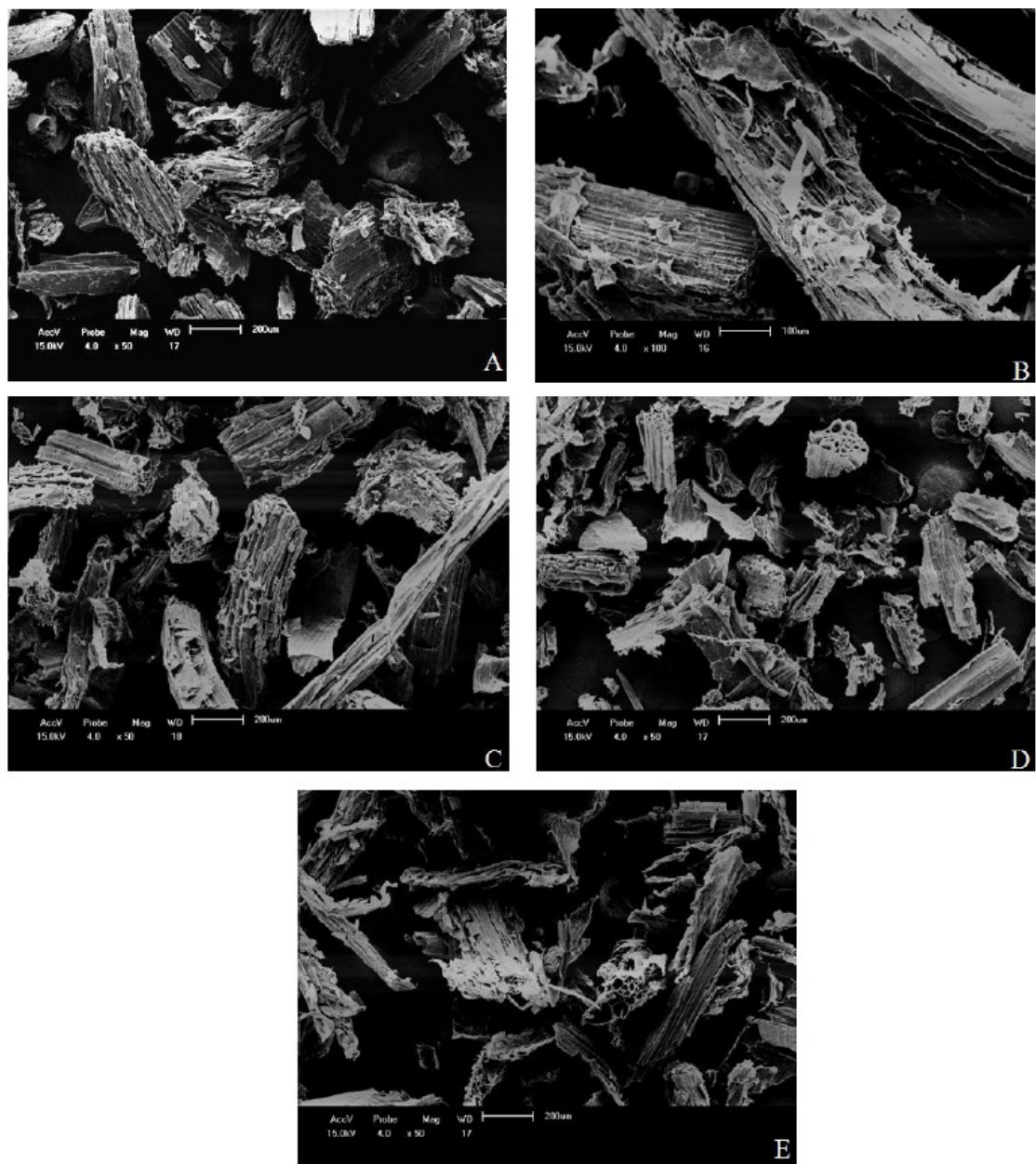

Figure 2: Scanning electron microscopy of fiber concentrates obtained from asparagus by-products. A - fiber concentrates produced without aqueous extraction step, B - fiber concentrates obtained by shaker treatment, C fiber concentrates obtained by homogenizer treatment, D - fiber concentrates obtained by ultrasound treatment, E - fiber concentrates obtained by water bath treatment.

The images confirmed that fibers are the main component of the products. There are residues of parenchyma and sclerenchyma. The cell wall of parenchyma tissue is relatively thin and formed of cellulose and hemicellulose, with a layer of pectic substances. It can be also observed some xylem vessels that exhibited scalariform thickening in lateral wall, characterized by deposition of lignin and hemicelluloses. The main role of these vessels is to conduct water and minerals to the plant (Rudall, 2007).

\section{CONCLUSIONS}

The fiber concentrates produced from asparagus byproducts had high content of dietary fiber and antioxidant compounds, but, among the water extraction treatments the one realized in ultrasound was highlighted due to the better balance of soluble and insoluble fibers, low sugar content, high antioxidant potential and lighter color, characteristics that facilitate its addition in a functional product. Otherwise, the control treatment had the lowest cost of production and the highest content of proteins and ashes, and so, it can be also applied, mainly when the coloration and the sugar content do not interfere in the desired characteristics of the product formulated.

\section{ACKNOWLEDGEMENTS}

We would like to thank Dra. Camila da Silva for the technical support in the ultrasound equipment. 


\section{REFERENCES}

AYALA-ZAVALA, J. F. et al. Agro-industrial potential of exotic fruit byproducts as a source of food additives. Food Research International, 44(7):1866-1874, 2011.

AZIZ, N. A. A. et al. Chemical and functional properties of the native banana (Musa acuminate x Balbisiana colla cv. Awak) pseudostem and pseudo-stem tender core flours. Food Chemistry, 128(3):748-753, 2011.

BENZIE, I. F. F.; STRAIN, J. J. The ferric reducing ability of plasma (FRAP) as a measure of "antioxidant power": The FRAP assay. Analytical Biochemistry, 239(1):70-76, 1996.

BOLANHO, B. C.; DANESI, E. D. G.; BELÉIA, A. D. P. Characterization of flours made from peach palm (Bactris gasipaes Kunth) byproducts as a new food ingredient. Journal of Food and Nutrition Research, 53(1):51-59, 2014.

BRAND-WILIAMS, W.; CUVELIER, M. E.; BERSET, C. Use of a free radical method to evaluate antioxidant activity. Food Science and Technology, 28(1):25-30, 1995.

CADAVID, E. L. A.; MOLINA, D. A. R.; VALENZUELA, J. R. C. Chemical, physicochemical and functional characteristics of dietary fiber obtained from asparagus byproducts (Asparagus officinalis L.). Revista Facultad Nacional de Agronomía, 68(1):7533-7544, 2015.

CHEMAT, F. et al. Ultrasound assisted extraction of food and natural products. Mechanisms, techniques, combinations, protocols and applications. A review. Ultrasonics Sonochemistry, 34:540-560, 2017.

CHEN, J. et al. Effect of microfluidization process on the functional properties of insoluble dietary fiber. Food Research International, 54(2):1821-1827, 2013.

DAIUTO, E. R. et al. Chemical composition and antioxidant activity of the pulp, peel and by products of avocado "Hass". Revista Brasileira de Fruticultura, 36(2):417-424, 2014.

DANG, T. T.; VASANTHAN, T. Modification of rice bran dietary fiber concentrates using enzyme and extrusion cooking. Food Hydrocolloids, 89:773-782, 2019.

ELLEUCH, M. et al. Dietary fibre and fibre-rich by-products of food processing: Characterization, technological functionality and commercial applications: a review. Food Chemistry, 124(2):411-421, 2011.

FAN, R. et al. Extraction and analysis of antioxidant compounds from the residues of Asparagus officinalis L. Journal of Food Science and Technology, 52(5):2690-2700, 2015.
FAO. On-line Statistical Database of the Food and Agricultural Organization of the United Nations. Available in: <http:// faostat3.fao.org/>. Access in: August, 312018.

FERARSA, S. et al. Recovery of anthocyanins and other phenolic compounds from purple eggplant peels and pulps using ultrasonic-assisted extraction. Food and Bioproducts Processing, 109:19-28, 2018.

FUENTES-ALVENTOSA, J. M. et al. Effect of the extraction method on phytochemical composition and antioxidant activity of high dietary fibre powders obtained from asparagus byproducts. Food Chemistry, 116(2):484-490, 2009a.

FUENTES-ALVENTOSA, J. M. et al. Effect of extraction method on chemical composition and functional characteristics of high dietary fibre powders obtained from asparagus byproducts. Food Chemistry, 113(2):665-671, 2009b.

GUO, R.; WEI, P.; LIU, W. Combined antioxidant effects of rutin and Vitamin C in Triton X-100 micelles. Journal of Pharmaceutical and Biomedical Analysis, 43(4):15801586, 2007.

HORWITZ, W.; LATIMER, G. W. Official methods of analysis of AOAC International. Gaithersburg: Association of Official Analytical Chemists, 2005. 1094p.

HUNG, P. V. et al. Total phenolic compounds and antioxidant capacity of wheat graded flours by polishing method. Food Research International, 42(1):185-190, 2009.

IWASSA, I. J. et al. Effect of subcritical water processing on the extraction of compounds, composition, and functional properties of asparagus by-product. Journal of Food Process Engineering, 42 (4):e13060, 2019.

JITNGARMKUSOL, S.; HONGSUWANKUL, J.; TANANUWONG, K. Chemical compositions, functional properties, and microstructure of defatted macadamia flours. Food Chemistry, 110(1):23-30, 2008.

KUNZEK, $\mathrm{H}$. et al. The significance of physico chemical properties of plant cell wall materials for the development of innovative food products. European Food Research and Technology, 214(5):361-376, 2002.

MCLELLAN, M. R.; LIND, L. R.; KIME, R. W. Hue angle determinations and statistical analysis for multiquadrant hunter L, a, b Data. Journal of Food Quality, 18(3):235240, 1995.

MUDGIL, D.; BARAK, S.; KHATKAR, B. S. Process optimization of partially hydrolyzed guar gum using response surface methodology. Agro Food Industry Hi-tech, 23(1):13-15, 2012. 
M'HIRI, M. et al. Effect of different drying processes on functional properties of industrial lemon byproduct. Process Safety and Environmental Protection, 116:450460, 2018.

OLIVEIRA, L. L.; CARVALHO, M. V.; MELO, L. Health promoting and sensory properties of phenolic compounds in food. Revista Ceres, 61:764-779, 2014.

PSZCZOLA, D. E. Fiber's new visibility. Food Technology, 62(12):61-71, 2008.

ROCKENBACH, I. I. et al. Phenolic compounds and antioxidant activity of seed and skin extracts of red grape (Vitis vinifera and Vitis labrusca) pomace from Brazilian winemaking. Food Research International, 44(4):897-901, 2011.

ROMDHANE, N. G. et al. Effect of air-drying temperature on kinetics of quality attributes of lemon (Citrus limon cv. lunari) Peels. Drying Technology, 33(13):1581-1589, 2015.

RUDALL, P. S. Anatomy of flowering plants. Introduction to structure and development. Cambridge: Cambridge University Press, 2007. 158p.

SEIBEL, N. F.; BELÉIA, A. D. P. Características químicas e funcionalidade tecnológica de ingredientes de soja [Glycine Max (L.) Merrill]: Carboidratos e proteínas. Brazilian Journal of Food Technology, 12(2):113-122, 2009.

SERGIO, L. et al. Effect of cooking and packaging conditions on quality of semi-dried green asparagus during cold storage. LWT - Food Science and Technology, 89:712-718, 2018.
SUN, T.; TANG, J.; POWERS, J. R. Effect of pectolytic enzyme preparations on the phenolic composition and antioxidant activity of asparagus juice. Journal of Agricultural and Food Chemistry, 53(1):42-48, 2005.

SWAIN, T.; HILLIS, W. E. The phenolic constituents of Prunus domestica - The quantitative analysis of phenolic constituents. Journal of Science Food Agriculture, 10(1):63-68, 1959.

TABASZEWSKA, M. et al. Effect of fermentation and storage on the nutritional value and contents of biologically-active compounds in lacto-fermented white asparagus (Asparagus officinalis L.). LWT - Food Science and Technology, 92:67-72, 2018.

TSUSHIDA, T; SUZUKI, M; KUROGI, M. Evaluation of antioxidant activity of vegetable extracts and determination of some active compounds. Japanese Society for Food Science and Technology, 41(9):611-618, 1994.

VEDANA, M. I. S et al. Efeito do processamento na atividade antioxidante de uva. Brazilian Journal of Food and Nutrition, 19(2):159-165, 2008.

VIUDA-MARTOS, M. et al. Chemical, physico-chemical and functional properties of pomegranate (Punica granatum L.) bagasses powder co-product. Journal of Food Engineering, 110(2):220-224, 2012.

ZHAO, J. et al. The aqueous extract of Asparagus officinalis L. by-product exerts hypoglycaemic activity in streptozotocininduced diabetic rats. Journal of the Science of Food and Agriculture, 91(11):2095-2099, 2011. 